\title{
ANALISIS KECUKUPAN MODAL KERJA DALAM SISTEM TANGGUNG RENTENG PADA KSU SETIA BUDI WANITA MALANG
}

\author{
Meldona \\ Yofa Faridah Wulansari \\ Fakultas Ekonomi UIN Maulana Malik Ibrahim Malang \\ Jl. Gajayana 50 Malang Telepon (0341) 558881 \\ email: meldona_nurlatifa@yahoo.co.uk
}

\begin{abstract}
Funds used to carry out daily operational activities are called working capital. Working capital is expected to be able to return in cash to the company within a specified period through the sale of production and revenue services. In a Cooperative, the optimal working capital is also required to maximize profitability. This research aim was to measure the level of adequacy of working capital in improving the profitability of the cooperative in joint responsibility implementation. This type of research is a qualitative descriptive approach, hereinafter referred to descriptive qualitative research is by doing interviews with the management of Cooperatives and analyzing the financial statements. This research was conducted at Setia Budi Wanita Cooperative in Malang. Results indicate that working capital is owned by cooperative $S B W$ is not fully optimal in improving profitability. This is indicated in GPM and ROA ratios that are declining. But when seen from the ratio of $R O E$, the cooperative has been able to maximize service revenue and sales to repay its debts.
\end{abstract}

Keywords: Modal kerja, profitabilitas, sistem tanggung renteng, koperasi

Modal kerja dibutuhkan oleh setiap perusahaan untuk membiayai kegiatan operasinya sehari-hari, di mana modal kerja yang telah dikeluarkan itu diharapkan akan dapat kembali lagi diterima perusahaan dalam waktu yang pendek melalui hasil penjualan produknya. Modal kerja yang berasal dari penjualan produk tersebut akan segera dikeluarkan lagi untuk membiayai kegiatan operasional selanjutnya (Riyanto, 2001). Menurut Copeland dan Weston (1992) modal kerja merupakan investasi perusahaan dalam bentuk uang tunai, surat berharga, piutang dan persediaan dikurangi kewajiban lancar yang digunakan untuk membiayai aktiva lancar. Setiap elemen dari aktiva lancar tersebut harus dikelola secara efisien agar meningkatkan likuiditas perusahaan pada tingkat aman.

Meilani (2009) menyatakan besar kecilnya modal kerja perusahaan tergantung dari jenis perusahaan. Penentuan jumlah modal kerja sangatlah penting bagi perusahaan, karena jika kekurangan modal kerja maka perusahaan akan mengalami masalah likuiditas yaitu tidak bisa membayar kewajiban jangka pendek tepat pada waktunya, misalnya kesulitan dalam membeli bahan baku atau bahan pembantu, membayar upah buruh, gaji para karyawan, serta biaya-biaya lainnya yang akan mengakibatkan tidak maksimumnya kegiatan operasional 
perusahaan. Sedangkan jika kelebihan modal kerja dapat mengakibatkan kerugian bagi perusahaan, hal ini dikarenakan adanya idle money yang tidak dialokasikan untuk pos yang lain. Kelebihan modal kerja berarti menunjukkan adanya dana yang tidak produktif, ini akan mengurangi kesempatan dalam memperoleh keuntungan. Uang atau dana yang dikeluarkan itu diharapkan dapat masuk kembali dalam perusahaan dalam waktu yang pendek melalui hasil penjualan produksinya maupun untuk jangka panjang melalui investasinya. Uang masuk yang berasal dari penjualan produk tersebut akan segera dikeluarkan lagi untuk membiayai operasi selanjutnya. Dengan demikian, maka dana tersebut akan terus menerus berputar setiap periodenya, selama hidupnya perusahaan tersebut. Kamarudin (1997) menyatakan bahwa kecukupan modal kerja berpengaruh terhadap efisiensi dan efektivitas dalam mengoperasikan perusahaan dan mengurangi keadaan yang timbul akibat adanya kekacauan keuangan perusahaan. Dengan menganalisa efisiensi dan efektivitas penggunaan modal kerja dapat diketahui bagaimana kebijaksanaan yang akan ditempuh oleh suatu perusahaan dalam usahanya mengoperasikan modal yang ada sehingga dapat diketahui tingkat efisiensi dan efektivitas dari modal yang dioperasikan.

Demikian pula yang dijelaskan oleh Tunggal (1995) bahwa indikasi pengelolaan modal kerja yang baik adalah adanya efisiensi modal kerja yang dapat dilihat dari perputaran modal kerja yang dimiliki dari aset kas diinvestasikan dalam komponen modal kerja sampai saat kembali menjadi kas. Efisiensi modal kerja dapat dilihat dari perputaran kas, persediaan, piutang dan modal kerja itu sendiri. Perputaran modal kerja dimulai dari saat kas diinvestasikan dalam komponen modal kerja sampai saat menjadi kas. Makin pendek periode perputaran modal kerja makin cepat perputarannya, sehingga modal kerja semakin tinggi dan perusahaan makin efisien yang pada akhirnya profitabilitas meningkat.

Koperasi menjadi salah satu jenis usaha yang berkembang dan berperan besar dalam perekonomian di Indonesia. Hudiyanto (2002) menjelaskan seperti halnya perusahaan jenis lain, koperasi pun harus melakukan perputaran modal kerja untuk menjalankan kegiatan operasionalnya. Namun berbeda dengan perusahaan jenis lain, modal koperasi berupa modal sendiri maupun dari pinjaman. Modal sendiri berasal dari seluruh kebutuhan modal untuk memulai serta mengembangkan usaha koperasi dipikul bersama-sama oleh seluruh anggota dengan jalan menabung secara teratur dan tertib dalam bentuk simpanan anggota yang terdiri dari simpanan wajib, simpanan pokok, maupun simpanan sukarela, serta hasil yang tidak dibagikan. Sedangkan modal pinjaman di koperasi dapat diperoleh dari anggota, dari perorangan bukan anggota, dari koperasi lain, dari perusahaan swasta, maupun dari bank. Dalam hal ini, modal pinjaman merupakan hutang bagi koperasi. 
Modal pinjaman diperlukan koperasi karena dalam memenuhi kebutuhan dananya koperasi akan kesulitan apabila hanya dari modal sendiri saja. Modal pinjaman merupakan alternatif bagi koperasi, karena kecil dan terbatasnya jumlah dana dari modal sendiri. Jika tambahan modal tersebut diperoleh dari modal pinjaman, maka koperasi akan menanggung beban yaitu berupa bunga yang harus dibayarkan atas pinjaman tersebut. Semakin besar modal yang dipinjam oleh koperasi maka semakin besar pula bunga yang harus ditanggung oleh koperasi. Lebih jauh, dijelaskan oleh Hendar dan Kusnadi (2005), bahwa koperasi harus mempertimbangkan berapa jumlah modal yang akan dipinjam agar efisien, karena jika koperasi kelebihan modal justru akan mengakibatkan adanya dana menganggur, namun jika pinjaman dilakukan dalam jumlah terlalu besar, maka biaya bunga yang ditanggung akan terlalu tinggi, yang merugikan koperasi. Sebaliknya apabila terjadi kekurangan modal kerja, maka kegiatan operasional koperasi akan terhambat (http://www.koperasiukm.com).

Dalam mengurangi tingkat resikonya, sejumlah koperasi memiliki sistem unik yang tidak dimiliki oleh perusahaan jenis lainnya yaitu sistem tanggung renteng. Sistem tanggung renteng merupakan sebuah sistem pengelolaan risiko dalam sebuah organisasi yang diwujudkan dengan berbagi tanggung jawab pada seluruh anggota kelompok secara proporsional (Arifin, 2008). Sistem ini juga berlaku dalam pengelolaan keuangan, termasuk kecukupan modal kerja koperasi. Sementara definisi tanggung renteng (TR) menurut Koperasi Setia Budi Wanita Malang adalah bahwa tanggung jawab bersama seluruh anggota di satu kelompok atas segala kewajibannya terhadap koperasi dilakukan atas dasar keterbukaan dan saling mempercayai untuk mewujudkan wadah interaksi manusia yang dialogis menuju manusia berkualitas. Lebih jelas lagi diartikan bahwa tanggung renteng dipandang sebagai bentuk sistem maksimalisasi peran anggota di kelompoknya masingmasing dalam pelaksanaan seluruh program kerja yang ada di koperasi dalam bentuk kolektifitas atau kerjasama antar anggotanya.

Koperasi Serba Usaha Setia Budi Wanita (Koperasi SBW) Malang merupakan salah satu koperasi yang sukses dalam mengaplikasian sistem tanggung renteng di Jawa Timur, khususnya di kota Malang, yang ditandai dengan jumlah keanggotaannya sebesar lebih dari 6000 orang pada tahun 2012 dengan menghimpun dana sebesar 13 Milyar rupiah berupa tabungan anggota dan 11 Milyar rupiah berupa simpanan pokok dan wajib anggota. Sejak berdiri pada tahun 1954, yang semula berupa pertemuan rutin ibu-ibu, Koperasi SBW sempat vakum beberapa tahun, kemudian menjadi pra-koperasi, dan pada tahun 1977 menerima Bahan Hukum Koperasi. Selama tiga tahun berikutnya Koperasi SBW berkembang cukup pesat sampai menerima penghargaan tingkat nasional ke-II sebagai Koperasi Non-KUD 
terbaik pada tahun 1979. Namun di tahun 1982, Koperasi SBW jatuh bangkrut yang disebabkan oleh miss manajemen dan ketidaksiapan pengelolaan dana anggota yang pada saat itu mencapai 5.000 orang. Tahun 1987, Koperasi SBW bangkit kembali dengan bantuan Puskowanjati (Pusat Koperasi Wanita Jawa Timur). Pada tahun 2005, Koperasi SBW dapat menyelesaikan pinjaman substitusi pada Bank Indonesia, melalui tanggung renteng. Dan pada tahun 2007 akhirnya Koperasi SBW Malang mampu mencapai sukses kembali dengan membukukan SHU senilai 99 juta rupiah (http://www.sbw-malang.net).

Jelas telah terjadi peningkatan yang signifikan semenjak awal kebangkitannya di tahun 2007. Total hutang Koperasi SBW Malang pun kini hanya seperempat dari total aset. Jumlah aset yang tidak sedikit tersebut merupakan buah dari usaha Koperasi dalam mempertahankan komunikasi dan transparansi yang baik antara pengurus dengan anggotanya dalam penerapan tanggung renteng sebagai sebuah sistem yang digunakan untuk mengatasi masalah yang ada. Sistem tanggung renteng dianggap mampu mengurangi angka kredit macet dari para anggotanya secara keseluruhan, bahkan sampai pada tingkat 0\% (tidak ada kredit yang macet), sehingga berdampak pada meningkatnya tingkat keuntungan yang diterima anggota. Secara langsung, sistem tersebut berhubungan erat dengan kemampuan Koperasi dalam memenuhi kebutuhan modal kerjanya (Rahayu, 2008).

Berdasarkan latar belakang penelitian dan masalah penelitian, maka yang menjadi tujuan penelitian ini adalah: (1) Menghitung kebutuhan modal kerja yang optimal guna meningkatkan profitabilitas pada Koperasi Serba Usaha Setia Budi Wanita Malang, dan (2) Mendeskripsikan pengelolaan modal kerja dengan sistem Tanggung Renteng guna meningkatkan profitabilitas Koperasi Serba Usaha Setia Budi Wanita Malang.

\section{METODE}

Penelitian ini merupakan penelitian lapangan, dengan jenis penelitian kualitatif dengan pendekatan deskriptif (Indriantoro, 2002), yang dilakukan di Koperasi Setia Budi Wanita (SBW) Malang, yang berada di Jalan Trunojoyo No. 76 Malang. Data primer diperoleh dari wawancara mendalam dengan pertanyaan yang terstruktur kepada pengurus koperasi tentang kondisi umum dan program-program kegiatan usaha koperasi, serta pengelolaan modal kerja. Sementara data sekunder diperoleh berupa dokumen kebijakan, meliputi Anggaran Dasar dan Anggaran Rumah Tangga Koperasi, profil koperasi, notulen rapat kerja serta laporan keuangan yaitu laporan laba rugi dan neraca periode 2009-2011. Analisis data yang dilakukan untuk mengukur kebutuhan modal kerja yang optimal guna meningkatkan profitabilitas, 
(Munawir, 2002), (Husnan, 1997), (Djarwanto, 2000), (Mutmaidah, 2010), (Rahmawati, 2008), (Sartono, 1998), (Subardi, 1995) meliputi: Analisis Kecukupan Modal Kerja dan analisis Profitabilitas

Selanjutnya tahap-tahap dalam menganalisis data laporan keuangan sebagai berikut: (a) Menyusun neraca perbandingan tahun 2009-2011, (b) Menganalisis laporan perubahan modal tahun 2009-2011, (c) Menganalisis laporan kebutuhan modal kerja 2009-2011 dengan metode perputaran modal kerja, (d) Menganalisis perhitungan profitabilitas 2009-2011. Sedangkan untuk menjawab permasalahan kedua tentang pengelolaan modal kerja dengan sistem Tanggung Renteng guna meningkatkan profitabilitas Koperasi Serba Usaha Setia Budi Wanita Malang, maka dilakukan tahap-tahap penelitian berikut: (a) Menganalisis implementasi sistem tanggung renteng di Koperasi Serba Usaha SBW Malang. (b) Menganalisis hubungan antara penggunaan sistem tanggung renteng dengan kecukupan modal kerja Koperasi.

\section{HASIL DAN PEMBAHASAN}

Setelah disusun neraca perbandingan, analisis perhitungan kecukupan modal kerja dan rasio profitabilitas menunjukkan hasil sebagai berikut:

$\begin{gathered}\text { Analisis Kecukupan Modal Kerja Untuk Meningkatkan Modal Kerja } \\
\text { pada Koperasi SBW Malang untuk periode 2009-2011 }\end{gathered}$
\begin{tabular}{|l|c|c|c|}
\hline \multirow{2}{*}{ Keterangan } & \multicolumn{3}{|c|}{ Tahun } \\
\cline { 2 - 4 } & $\mathbf{2 0 0 9}$ & $\mathbf{2 0 1 0}$ & $\mathbf{2 0 1 1}$ \\
\hline Perubahan Modal Kerja & \multicolumn{3}{|c|}{} \\
& 2.058 .806 .661 & \multicolumn{2}{|c|}{6.061 .216 .326} \\
\hline Perputaran Modal Kerja & $\mathbf{2 0 . 1 5 1 . 5 1 7 . 9 6 1}$ & $\mathbf{2 1 . 8 2 0 . 9 3 2 . 2 7 2}$ & $\mathbf{3 0 . 6 6 7 . 5 0 1 . 9 5 5}$ \\
\hline $\begin{array}{l}\text { Rasio Profitabilitas: } \\
\text { GPM }\end{array}$ & $43 \%$ & $40 \%$ & $44 \%$ \\
\hline NPM & $2 \%$ & $2 \%$ & $2 \%$ \\
\hline ROA & $1,02 \%$ & $0,94 \%$ & $0,7 \%$ \\
\hline ROE & $2,48 \%$ & $2,42 \%$ & $1,9 \%$ \\
\hline
\end{tabular}

Sumber : Data diolah

Tabel tersebut menunjukkan besarnya modal kerja yang dibutuhkan dengan menggunakan metode perputaran dari tahun 2009 hingga 2011 mengalami peningkatan. Hal tersebut terjadi karena Koperasi tiap tahunnya semakin membutuhkan dana untuk kegiatan operasionalnya, selain juga untuk meningkatkan pendapatan. Meningkatnya kebutuhan dana tersebut disertai juga dengan tingginya tingkat perputaran unsur modal kerja terutama 
piutang. Besarnya kebutuhan modal kerja jika dihitung dengan metode perputaran berturutturut mulai tahun 2009, 2010 dan 2011 adalah Rp 20.151.517.961, Rp 21.820.932.272, dan Rp. 30.667.501.955. Tiap tahunnya terjadi kenaikan kebutuhan modal kerja. Kemudian jika dibandingkan dengan realita yang ada, dengan analisa perubahan modal kerja menggunakan konsep kualitatif (kelebihan aktiva lancar diatas hutang lancar) pada periode 2009-2010 terjadi kenaikan modal kerja di Koperasi SBW Malang yaitu sebesar Rp 2.058.806.661 dan pada periode 2010-2011 sebesar 6.061.216.326. Perbandingan ini membuktikan bahwa pada kenyataannya peningkatan modal kerja yang digunakan koperasi lebih besar dibandingkan selisih dari analisis kebutuhan modal kerja tiap tahunnya.

Analisis kecukupan modal kerja juga terkait dengan kemampuan Koperasi SBW Malang dalam melakukan perputaran unsur-unsur modal kerjanya yaitu kas, piutang dan persediaan. Hasil perhitungan perputaran kas dari periode 2009-2011 menunjukkan peningkatan. Semakin tinggi tingkat perputaran kas berarti semakin efisien penggunaan kas. Dalam prakteknya, Koperasi SBW Malang menerapkan sistem kas kecil sebagai salah satu pengendalian untuk meminimalisir idle money. Kas kecil yang dimiliki Koperasi SBW Malang disediakan sebesar 1 juta rupiah tiap harinya. Penarikan uang dalam jumlah besar dilakukan di Bank ataupun di brankas koperasi dan tanggung jawab hanya pada dua pengurus saja yaitu Ketua dan Bendahara sehingga kerahasiaan terjamin. Kas kecil dipergunakan sebagai pengontrol uang keluar dan masuk di koperasi.

Sedangkan dari unsur piutangnya, tingkat perputarannya masih rendah karena piutang Koperasi SBW Malang belum mampu kembali dalam waktu yang cepat, rata-rata tiap tahunnya masih lebih dari satu tahun. Ini dikarenakan tingkat piutang yang cukup tinggi. Tingginya angka piutang usaha dikarenakan adanya unit simpan pinjam di koperasi. Unit tersebut merupakan unit unggulan yang dimiliki koperasi karena tiap tahunnya sebagian besar piutang berasal dari unit simpan pinjam. Salah satu manfaat dari adanya unit ini adalah berkurangnya idle money yang ada di koperasi. Dari hasil analisis persediaan, dari periode 2009 hingga 2011 perputarannya fluktuatif. Jika dilihat dari perhitungan di tiap unsur modal kerja (kas, piutang dan persediaan) secara keseluruhan, keterikatan dana Koperasi hasilnya lebih dari 360 hari atau 1 tahun. Ini menandakan bahwa koperasi masih belum bisa melakukan perputaran modal kerja dengan cepat.

Dalam kaitannya dengan profitabilitas Koperasi, analisis yang dilakukan adalah dengan menghitung rasio GPM, NPM, ROA dan ROE. Rasio GPM menunjukkan penurunan, hal tersebut diakibatkan oleh selisih antara penjualan, yang terdiri dari penjualan barang dan pendapatan jasa, dengan beban pokok penjualan pada tahun 2009-2010 menurun. Sehingga 
dapat dikatakan bahwa pendapatan belum efektif dalam menekan beban pokok penjualan. Hasil dari rasio NPM dari tahun 2009-2011 menunjukkan kestabilan Koperasi SBW Malang dalam menghasilkan laba bersih di setiap Rp. 1 penjualannya. Teori yang ada menyebutkan bahwa semakin tinggi tingkat NPM berarti semakin baik pula kemampuan koperasi dalam menaikkan laba bersih. Cara yang dilakukan untuk meningkatkan NPM adalah dengan memperbesar menaikkan harga penjualan dan pendapatan jasa per unit.

Hasil dari perhitungan rasio ROA dari tahun 2009 hingga tahun 2011 mengalami penurunan. Hasil tersebut menunjukkan kemampuan aktiva Koperasi SBW Malang dalam menghasilkan laba bersih dari modal atau dana yang dimiliki semakin menurun. Sedangkan dari hasil perhitungan rasio ROE dari tahun 2009-2011 mengalami penurunan. Semakin rendah presentase rasio ini menunjukkan semakin kecil atau berkurangnya utang perusahaan. Pada prakteknya, Koperasi SBW Malang pada tahun 2009 hingga 2011 telah mampu membayar hutang dari pihak ketiga salah satunya yaitu Puskowanjati.

Secara umum, perhitungan rasio-rasio tersebut menunjukkan bahwa tingkat profitabilitas koperasi dapat dikatakan meningkat, terutama pada sektor penjualan dan modal sendirinya. Modal sendiri telah mampu mengurangi tingkat modal pinjaman yang dimiliki koperasi. Kekuatan modal sendiri tersebut mampu mengoptimalkan modal kerja koperasi untuk memenuhi kebutuhan operasionalnya. Pengelolaan Modal Kerja dengan Sistem Tanggung Renteng yang dilakukan oleh Koperasi SBW pada intinya menekankan maksimalisasi anggota dalam segala aktivitas koperasi. Karena pada hakikatnya anggota merupakan aset terpenting koperasi. Dengan dilibatkannya anggota di seluruh aktivitas, atau lebih disebut dengan transparansi koperasi, akan mempengaruhi anggota dalam berperan serta di koperasi terutama dalam hal membayar simpanan secara rutin, yang artinya memperkuat modal koperasi. Di sisi lain, sistem TR menjadi faktor yang menarik minat masyarakat untuk menjadi anggota karena kemudahan birokrasinya dalam menghadapi setiap permasalahan di kelompok.

Koperasi SBW Malang, yang menerapkan sistem TR semenjak awal berdirinya, memberdayakan anggotanya melalui training dan pendidikan pemantapan TR terutama untuk anggota baru. Penerapan sistem TR di Koperasi SBW Malang dilakukan dengan pembentukan kelompok. Tiap kelompok terdiri dari kurang lebih 20 orang dan satu orang sebagai penanggung jawab. Penanggung jawab (PJ) kelompok bertugas mengkondisikan anggotanya. Setiap satu bulan sekali PJ dan anggota melakukan pertemuan secara rutin setiap satu bulan sekali. Pertemuan rutin ini dilakukan untuk melakukan musyawarah guna mencapai persetujuan bersama yang meliputi beberapa hal, yaitu: 
a. Penerimaan anggota baru, baik tentang target minimal 2 orang tambahan anggota baru di setiap bulannya, juga tentang kriteria persyaratannya, bahwa anggota baru terutama harus mendapat persetujuan dari seluruh anggota kelompok.

b. Pengajuan pinjaman dari anggota kelompok koperasi beserta prosedurnya, terutama tentang adanya jaminan moral, bahwa citra tiap anggota yang melakukan pinjaman akan dinilai oleh anggota lainnya dalam kelompok tersebut dengan semua anggota harus menandatangani Surat Persetujuan Pinjaman (SPP).

c. Penyelesaian masalah akibat tidak dipenuhinya kewajiban salah satu anggota, yaitu dengan dana TR kelompok, tetapi jika kurang maka akan ditutup dengan pengumpulkan secara gotong royong dari seluruh anggota kelompok.

d. Penyelesaian masalah akibat anggota yang melanggar peraturan. Bagi anggota yang mangkir dari kewajibannya dalam mengangsur pinjaman kepada koperasi secara sengaja dan atau tanpa konfirmasi kepada PJ maupun anggota lainnya, maka akan dibahas pada pertemuan rutin dan diselesaikan oleh seluruh anggota kelompok. Hasil keputusan tersebut kemudian di share PJ kepada pengurus koperasi. Keputusan terburuk adalah mengeluarkan anggota tersebut dari koperasi SBW Malang.

Fungsi TR di koperasi SBW Malang adalah sebagai pemberdayaan dan modifikasi perilaku. Koperasi dengan menerapkan sistem TR mampu memberdayakan seluruh anggotanya yang wanita menjadi mandiri, kreatif dan inovatif dalam kehidupan sehari-hari. Serta mampu membentuk perilaku para anggotanya kearah yang lebih baik, meliputi solidaritas, demokrasi, keterbukaan, kejujuran, kemandirian dan kepedulian. Penerapan sistem TR pada Koperasi SBW Malang meliputi: (1) proses pengambilan keputusan, yaitu tentang penerimaan dan pengeluaran anggota, pengajuan pinjaman dan sistem pembayaran; (2) masalah finansial, yaitu apabila ada anggota yang tidak mampu membayar angsuran, maka ditanggung seluruh anggota kelompok; (3) menghadapi resiko usaha, bahwa resiko terburuk adalah ketika koperasi collapse, maka anggota kelompok harus siap menanggung resiko tersebut dengan menentukan kebijakan kelompok. (4) memikul beban organisasi terutama menyangkut masa depan koperasi, yang akan dibahas pada RAT dan RAPB, dengan dihadiri oleh perwakilan dari seluruh kelompok (satu kelompok diwakili PJ dan asisten) termasuk membahas tentang program kerja dan rencana Koperasi untuk satu periode.

Dalam penelitian ini, penerapan TR yang dimaksud adalah dalam menghadapi masalah finansial dalam hal ini kaitannya dengan modal yang juga berpengaruh pada profitabilitas Koperasi. Berikut skema pengelolaan modal kerja dengan penggunaan sistem TR. 


\section{Gambar 1. Penerapan Sistem TR Dalam Permodalan Koperasi SBW Malang}

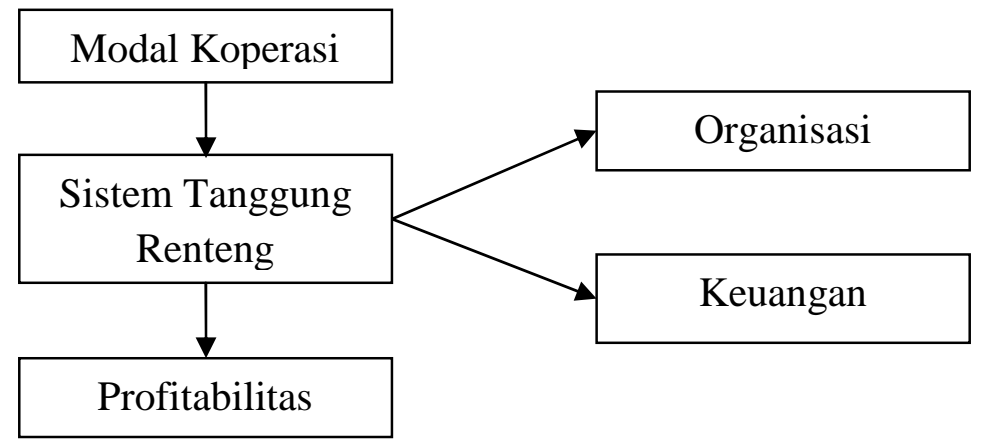

Sumber: Koperasi SBW Malang 2012 (diolah)

Modal Koperasi SBW Malang secara garis besar terdiri atas dua hal yaitu modal sendiri dan pinjaman. Modal sendiri dihimpun dari anggota yang berupa simpanan pokok, simpanan wajib dan sukarela. Sedangkan modal pinjaman terdiri dari pinjaman dari pemerintah (LPDB), pinjaman Puskowanjati, KPI dan pinjaman dari BPR Jatim. Untuk mengurangi jumlah modal pinjaman, maka Koperasi harus memperbesar jumlah modal sendiri. Adapun prosentase yang menjadi patokan Koperasi SBW tiap tahunnya adalah 70\% modal sendiri dan $30 \%$ modal pinjaman. Tingginya perencanaan prosentase modal sendiri mengharuskan Koperasi mengambil langkah konkrit guna memaksimalkan anggotanya dalam mendukung program peningkatan modal sendiri tersebut. Untuk itu Koperasi menggunakan sistem TR sebagai pemecahan masalah ini.

Penerapan TR sebagai pemecahan masalah permodalan koperasi pada dasarnya menitikberatkan pada anggota. Anggota menjadi aset penting koperasi yang harus dipertahankan. Dalam mempertahankan dan juga menambah jumlah anggota, koperasi perlu mengadakan suatu inovasi yang dapat menarik minat masyarakat. TR menjadi satu inovasi bagi koperasi dalam mempertahankan anggota dan bahkan menarik minat masyarakat terhadap koperasi simpan pinjam. Kemudahan yang disajikan dalam penerapan TR khususnya dalam melakukan simpan pinjam di koperasi menjadi salah satu daya tarik koperasi SBW Malang. Dengan adanya TR, prosedur simpan pinjam menjadi lebih praktis karena semua keputusan ada di tangan kelompok tanpa melibatkan seluruh elemen koperasi. Alasan tersebut yang menjadikan masyarakat tertarik untuk menjadi anggota koperasi. Makin bertambahnya anggota koperasi kemudian semakin meningkatkan simpanan pokok dan wajib maupun sukarela dari anggota kepada koperasi.

Sistem TR di Koperasi SBW Malang mencakup dua hal yaitu organisasi dan keuangan. Dalam hal organisasi, TR berperan sebagai penguat aturan yang berlaku dalam perkoperasian. Aturan ini yang kemudian mengubah perilaku individu menjadi perilaku yang 
lebih disiplin, peduli dan gotong royong. Karena sistem TR lebih menekankan pada pengambilan keputusan yang dilakukan secara musyawarah dalam satu kelompok. Artinya, semua jenis permasalahan kelompok termasuk masalah pengajuan pinjaman, sistem pembayaran, penerimaan anggota baru, dan dikeluarkannya anggota.

Sedangkan dalam hal keuangan, TR berperan sebagai penguat modal yang ada di Koperasi dalam hal ini modal sendiri. Kuatnya modal sendiri ini kemudian yang akan mempengaruhi besarnya modal kerja yang ada di koperasi. Karena semakin tinggi modal sendiri yang dihimpun dari anggota, maka modal pinjaman atau hutang dari pihak lain akan berkurang. Berkurangnya hutang koperasi ini akan memaksimalkan modal sendiri yang ada untuk digunakan sebagai modal kerja. Dengan kuatnya modal koperasi, profitabilitas koperasi akan meningkat dan tingkat kesejahteraan anggota akan lebih baik dengan meningkatnya SHU anggota. Profitabilitas yang diutamakan dalam penerapan sistem TR adalah penekanan terhadap utang koperasi.

Keberhasilan sistem TR yang dilakukan Koperasi SBW Malang dibuktikan dengan semakin tingginya jumlah anggota yang masuk di tiap tahunnya dan mampu mengurangi resiko kredit macet dan gagal bayar para anggota koperasi hingga 0\% dan secara keseluruhan mampu memperbaiki tingkat kesejahteraan dan ekonomi anggota. Tidak adanya resiko kredit macet dan gagal bayar di koperasi dikarenakan semua masalah koperasi sudah diselesaikan di pertemuan kelompok. Sehingga koperasi tidak lagi menanggung resiko dan pelanggaran yang dilakukan anggotanya. Sistem TR yang diterapkan oleh koperasi mampu memodifikasi perilaku anggotanya sehingga menjadi lebih disiplin dalam melaksanakan program kerja koperasi di tiap periodenya. Sistem TR ini juga memberikan dampak positif bagi keberlangsungan Koperasi SBW Malang, karena pada dasarnya anggota merupakan aset terpenting dalam koperasi. Dengan TR maka kerja sama dan tolong menolong anggota dalam kelompok menjadi lebih terorganisir.

Implementasi sistem Tanggung Renteng (TR) dapat dipandang dari perspektif perwujudan budaya bangsa Indonesia yang juga sesuai dengan nilai-nilai ajaran agama Islam. Sistem TR yang diterapkan oleh Koperasi SBW merupakan wujud dari falsafah hidup bangsa Indonesia dan budaya yang telah mengakar pada seluruh jiwa masyarakat Indonesia, yaitu gotong royong. Gotong Royong dapat diartikan sebagai suatu kegiatan sosial yang menonjolkan rasa kebersamaan dengan adanya sikap sosial tanpa pamrih dari masing-masing individu untuk meringankan beban yang sedang dipikul bersama. Sikap gotong royong ini menjadi ciri khas bangsa Indonesia dari jaman dahulu hingga saat ini, karena tidak bisa 
ditemukan di negara lain, yang umumnya masyarakatnya menunjukkan sikap saling acuh tak acuh terhadap lingkungan di sekitarnya.

Selain itu, sistem tanggung renteng juga sejalan dengan ajaran Islam tentang perintah untuk mempergunakan harta yang dimiliki oleh setiap muslim untuk tidak hanya ditimbun saja, tetapi dipergunakan di jalan Allah SWT, (QS At-Taubah ayat 34), dan untuk memutar harta dalam aktifitas yang produktif melalui cara perdagangan atau bentuk investasi lainnya (HR. Malik dalam kitab al-Muwaththa'). Sistem pembagian SHU yang diterapkan pada Koperasi SBW Malang dalam Islam disebut sebagai bagi hasil. Dengan itu koperasi SBW Malang telah memanfaatkan harta sesama yaitu harta anggota untuk kemaslahatan bersama. Harta anggota yang berupa simpanan pokok dan simpanan wajib digunakan koperasi sebagai modal dan digunakan untuk meningkatkan profitabilitas koperasi yang kemudian akan dibagikan lagi kepada anggota. Untuk bisa mencapai tujuan bersama ini, penerapan sistem TR pada koperasi SBW Malang menjadi bagian dari strategi pencapaian tersebut. Dengan melakukan penguatan pada anggota maka tujuan bersama tersebut akan lebih mudah dicapai. Sesuai pula dengan syariat Islam tentang perintah untuk bermusyawarah, saling tolong menolong dan bekerja sama dalam berbagai hal yang baik, khususnya dalam firman Allah SWT. QS Al-Imran ayat 159 dan QS. Al-Maidah ayat 2.

Dalam QS Al-Imran ayat 159 dijelaskan bahwa dalam mencari solusi dari setiap permasalahan dapat dilakukan dengan musyawarah dan bertawakkal kepada Allah, juga dalam QS Al-Maidah ayat 2 dijelaskan tentang penegasan perintah Allah SWT akan kewajiban bagi umat muslim untuk tolong-menolong dalam kebaikan dan takwa, serta larangan untuk tolong-menolong dalam berbuat dosa dan permusuhan. Dalam sistem TR, kerja sama yang dijalin oleh setiap anggota dalam kelompok, wujudnya berupa musyawarah untuk mencapai mufakat dalam mencari solusi dari setiap permasalahan yang ada, misalnya tentang penentuan penerimaan anggota baru dan pengajuan pinjaman. Tolong menolong utamanya diwujudkan dalam penyelesaian masalah pengembalian angsuran pinjaman anggota, baik yang dikarenakan tidak terpenuhinya kewajiban atau yang disebabkan oleh pelanggaran/mangkir, maka penyelesaiannya akan ditanggung oleh seluruh anggota kelompok.

\section{Kesimpulan}

Jumlah kenaikan modal kerja koperasi SBW Malang lebih tinggi dibandingkan dengan perputaran modal kerja di tiap tahunnya. Kenaikan modal kerja pada tahun 2009 ke 
2010 sebesar Rp. 2.058.806.661, sedangkan selisih perputaran modal kerja tahun 2009 ke 2010 adalah sebesar Rp. 21.820.932.272 - Rp. 20.151.517.961 = Rp. 1.669.414.356. Angka tersebut menunjukkan bahwa pada realitanya koperasi SBW Malang memiliki kecukupan modal kerja. Namun penggunaan modal kerja koperasi belum dipergunakan secara optimal, yang ditunjukkan dengan antara lain oleh perputaran piutang yang memakan waktu lebih dari satu tahun. Lambatnya perputaran piutang tersebut disebabkan oleh lambatnya perputaran dana di unit usaha simpan pinjam. Namun pada unsur modal kerja yang lain yaitu kas dan persediaan, terjadi perputaran cukup baik. Jika dihubungkan dengan perhitungan rasio profitabilitas koperasi dengan menggunakan rasio GPM, NPM, ROA dan ROE, maka secara keseluruhan modal kerja sudah mampu membayar hutang koperasi pada pihak ketiga. Namun pada periode 2009-2011 tingkat pendapatan dan kemampuan koperasi dalam menghasilkan laba bersih dari modal sendiri menunjukkan penurunan yang diakibatkan kurangnya volume penjualan.

Sistem Tanggung Renteng yang diterapkan di Koperasi Setia Budi Wanita Malang mampu mengkombinasikan antara kepentingan organisasi dan keuangan dengan menekankan penguatan anggotanya dalam berperan di masing-masing kelompok. Di dalam kelompok akan diselesaikan segala permasalahan, baik tentang penerimaan anggota baru, proses pinjaman uang, permasalahan dalam pengembalian pinjaman serta apabila ada anggota yang melanggar. Terbukti sistem tersebut mampu menekan resiko kredit macet hingga 0\%, sehingga dapat memperbesar prosentase modal sendiri sekaligus akan mengurangi jumlah modal pinjaman koperasi. Kuatnya modal koperasi ditunjang dengan peran kelompok akan memaksimalkan penggunaan modal kerja koperasi, dan semakin kuat sistem tanggung renteng diterapkan di kelompok akan mampu meningkatkan profitabilitas koperasi. Penerapan sistem tanggung renteng juga sejalan dengan nilai-nilai yang dikandung dalam ajaran agama Islam, yaitu anjuran untuk mengelola harta sebagai amanah dari Allah SWT, bekerjasama dan saling tolong menolong dalam kebaikan, serta melakukan musyawarah dan tawakal untuk menyelesaikan segala permasalahan.

\section{Saran}

Dari penelitian yang dilakukan di Koperasi SBW Malang, maka peneliti dapat memberikan saran guna tercapainya perubahan yang lebih baik, antara lain:

Hendaknya koperasi menekankan untuk mengoptimalkan perputaran modal kerjanya, terutama tentang lambatnya perputaran piutang, yaitu dengan jalan memperbaiki sistem pembayaran angsuran pinjaman anggota. Misalkan dengan memberlakukan denda untuk 
setiap keterlambatan pembayaran angsuran pinjaman yang dananya kemudian dikumpulkan dan digunakan sebagai dana kelompok. Pemberlakuan denda tersebut berfungsi dalam mendisiplinkan anggota.

Koperasi dapat pula berupaya untuk meningkatkan jumlah anggota dengan jalan meningkatkan kualitas pertemuan rutin kelompok sebagai sarana saling mendekatkan diri antar anggota di masing-masing kelompok dan juga ke anggota kelompok yang lain. Pengurus koperasi dapat juga melakukan upaya promosi yang lebih intensif, sehingga masyarakat semakin kenal dan tertarik menjadi anggota. Semakin banyak anggota, maka akan semakin besar modal sendiri.

Meningkatkan pendapatan koperasi dengan meningkatkan pendapatan jasa dan penjualan. Hal tersebut dapat dilakukan dengan cara evaluasi terhadap manajemen produk yang selama ini terjadi. Jika dirasa perlu dapat dilakukan perubahan standar, baik terhadap kualitas produk serta harga, bisa pula dengan melakukan inovasi-inovasi program penjualan. Sedangkan untuk unit simpan pinjam perlu dievaluasi tentang sistem administrasi dan database-nya, sehingga kualitas layanan kepada anggota akan meningkat. Semakin tertib administrasi yang ditunjang oleh sistem informasi terkomputersasi yang baik, maka proses simpan pinjam akan lebih mudah. Pelayanan yang cepat akan menarik semakin banyak anggota koperasi yang melakukan simpan pinjam yang akhirnya akan meningkatkan pendapatan koperasi.

\section{DAFTAR PUSTAKA.}

Arifin, Syaiful. 2008. Dinamika Implementasi Konsep Sistem Tanggung Renteng dan Kontribusinya pada Tercapainya Zero Bad Debt, Jurnal Keuangan dan Perbankan. Volume 12 No.3 : 517-531.

Basith, Abdul. 2008. Islam dan Manajemen Koperasi. Malang: Penerbit UIN Malang Press.

Bunging, Burhan, 2001. Metodologi Penelitian Sosial Format-Format Kuantitatif dan Kualitatif. Surabaya: Penerbit Airlangga University Press.

Copeland, Thomas E., \& J Fred Weston. 1992. Financial Theory And Corporate Policy. $5^{\text {th }}$ Ed. USA: Addison-Wesley Publishing Company, Inc.

Djarwanto, PS. 2000. Pokok-Pokok Analisa Laporan Keuangan. Edisi Pertama, Cetakan Kedua. Yogyakarta: Penerbit BPFE.

Hendar dan Kusnadi, 2005. Ekonomi Koperasi (Untuk Perguruan Tinggi). Edisi Kedua, Jakarta: Penerbit FEUI.

Hendrojogi, 2000. Koperasi Azas-Azas, Teori dan Praktik. Edisi Revisi, Jakarta: Penerbit PT. Raja Grafindo Persada.

Hudiyanto, 2002. Sistem Koperasi Ideologi dan Pengelolaan. Yogyakarta: Penerbit UII Press. 
Husnan, Suad, 1997. Manajemen Keuangan Teori dan Penerapan (Keputusan Jangka Panjang). Yogyakarta: Penerbit BPFE.

Indriantoro, Nur \& Supomo, Bambang, 2002. Metodologi Penelitian Bisnis untuk Akuntansi dan Manajemen. Edisi Pertama. Yogyakarta: Penerbit BPFE.

Kamarudin, Ahmad. 1997. Dasar-Dasar Manajemen Modal Kerja. Jakarta: Penerbit PT.Rineka Cipta.

Meilani, Agustina. 2009. Analisis Efisiensi Penggunaan Modal Kerja pada CV. Arrahman Di Surakarta, Skripsi. Surakarta:FE-UNMUH

Munawir, S. 2002. Analisis Laporan Keuangan. Yogyakarta: Penerbit Liberty.

Mutmaidah, Siti. 2010. Analisis Rasio Sebagai Tolak Ukur Kinerja Keuangan Koperasi Agro Niaga (KAN) Jabung Malang Periode 2005-2009. Skripsi, Malang:FE UIN-MALIKI.

Rahayu, Yayuk. 2008. Penerapan Sistem Tanggung Renteng pada Koperasi Wanita Serba Usaha "Setia Budi Wanita" Malang. Malang: FE-UIN MALIKI.

Rahma, Aulia, 2011. Analisis Pengaruh Manajemen Modal Kerja Terhadap Profitabilitas Perusahaan, Skripsi. Semarang: FE-UNDIP

Rahman, Afzalur. 1995. Doktrin Ekonomi Islam Jilid 1. Penerjemah Soeroyo dan Nastangin, Jakarta: Penerbit Dana Bhakti Wakaf.

Rahmawati, Riris. 2008. Pengaruh Perputaran Modal Kerja Terhadap SHU (Studi Kasus di Koperasi Serba Usaha Al-Hikmah Tumpang Talun Blitar), Skripsi. Malang:FE-UIN MALIKI.

Riyanto, Bambang. 2001. Dasar-Dasar Pembelanjaan Perusahaan. Cetakan Ketujuh, Yogyakarta: Penerbit BEP.

Sartika, Titik Pramono dan Abd. Rachman Soejoedono, 2004. Ekonomi Skala Kecil/Menengah \& Koperasi. Bogor: Penerbit Ghalia Indonesia.

Sartono, Agus, R. Drs, MBA. 1998. Manajemen Keuangan Teori dan Aplikasi. Yogyakarta: Penerbit BPFE.

Sawir, Agnes. 2001. Analisis Kinerja Keuangan dan Perencanaan Keuangan Perusahaan. Jakarta: PT. Gramedia Pustaka Utama.

Subardi, Agus. 1995. Manajemen Keuangan. Jilid 1, Yogyakarta: Unit Penerbit dan Percetakan AMP YKPN.

Sugiyono. 2008. Metode Penelitian Kuantitatif Kualitatif dan R\&D. Bandung: Alfabeta.

Tunggal, Widjaja, Amin, 1995. Dasar-Dasar Analisis Laporan Keuangan. Yogyakarta: Penerbit Rhineka Cipta.

Undang-Undang Perkoperasian no. 25 Tahun 1992.

http://sbw-malang.net. 12 Maret 2012

http://www.koperasiukm.com. 12 Maret 2012

http://www.tanggungrenteng.com . 17 Maret 2012 